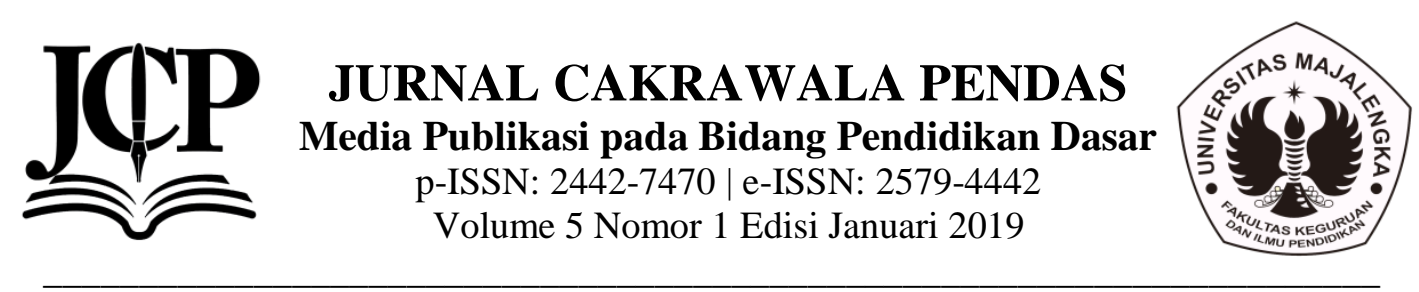

\title{
Pengembangan Perangkat Pembelajaran Matematika SD Kelas V Dengan Berbasis Pendekatan Saintifik Yang Berorientasi Pada Kemampuan Pemecahan Masalah Siswa
}

\author{
Dede Salim Nahdi, Ujiati Cahyaningsih \\ salimnahdi15@gmail.com, ujiati.cahyaningsih31@gmail.com \\ Universitas Majalengka
}

\begin{abstract}
Penelitian ini bertujuan menghasilkan perangkat pembelajaran matematika berbasis scientific approach yang berorientasi pada kemampuan pemecahan masalah bagi siswa kelas V SD. Penelitian ini merupakan penelitian dan pengembangan yang mengacu pada model ADDIE (Analysis, Design, Development, Implementation, dan Evaluation). Subjek uji coba siswa kelas V SDN Panyingkiran Majalengka. Hasil penelitian berupa perangkat pembelajaran matematika yang meliputi: Rencana Pelaksanaan Pembelajaran (RPP) dan Lembar Kerja Siswa (LKS). Hasilnya menunjukkan perangkat pembelajaran yang telah dikembangkan layak menurut ahli kurikulum, ahli materi dan ahli media dengan kategori penilaian sangat baik. Berdasarkan penilaian guru, perangkat pembelajaran yang dikembangkan telah memenuhi kriteria praktis dengan kualitas sangat baik. Adapun siswa menilai perangkat yang dikembangkan telah memenuhi kriteria praktis dengan kualitas baik.Perangkat pembelajaran dinilai efektif karena hasil tes kemampuan pemecahan masalah matematika menunjukkan ketuntasan siswa melebihi $80 \%$.
\end{abstract}

Kata Kunci: Pengembangan, Perangkat Pembelajaran, Pendekatan saintifik, kemampuan pemecahan masalah. 


\section{Pendahuluan}

Matematika merupakan mata pelajaran wajib yang diajarkan di sekolah. Setiap jenjang pendidikan yang ada di Indonesia mulai dari SD, SMP sampai SMA wajib mempelajari matematika. Dalam Permendikbud Nomor 057 Tahun 2014 pasal 5 ditegaskan bahwa matematika merupakan salah satu mata pelajaran umum yang wajib dipelajari siswa sekolah dasar.

Berdasarkan Permendikbud Nomor 057 Tahun 2014, salah satu tujuan mata pelajaran matematika adalah agar siswa memiliki kecakapan hidup dalam mengembangkan kemampuan pemecahan masalah-masalah yang dihadapi dalam kehidupan siswa seharihari.. Hal ini sejalan dengan pendapat National Council of Teachers of Mathematics (NCTM, 2009: 18) yang menyatakan bahwa salah satu tujuan pembelajaran matematika adalah mengembangkan kemampuan pemecahan masalah. Demikian dapat disimpulkan bahwa memecahkan masalah merupakan kemampuan yang penting dimiliki siswa. Pentingnya kemampuan memecahkan masalah ditegaskan oleh Suherman, dkk., (2003: 89) yang menjelaskan bahwa melalui kegiatan pemecahan masalah, dapat dikembangkan aspek-aspek kemampuan matematis lain seperti penerapan aturan pada masalah tidak rutin, penemuan pola, dan lainlain.

Kemampuan pemecahan masalah merupakan kemampuan siswa dalam menggunakan beberapa proses berpikir tingkat tinggi dalam rangka memperoleh solusi atas masalah yang dihadapi (Nitko \& Brookhart, 2011: 231). Menurut Sriraman \& English (2010: 265) kemampuan memecahkan masalah sangat bermanfaat dalam mengembangkan pemahaman dalam pengusaaan konsep. Ditegaskan juga oleh Wilis (2010: 4) yang mengemukakan siswa yang memiliki kompetensi matematika juga juga akan memiliki kemampuan kritis lainnya, seperti penalaran, abstraksi, pola dan pengenalan hubungan, dan pemikiran konseptual.

Mencermati begitu pentingnya kemampuan pemecahan masalah pada pembelajaran matematika maka siswa diharapkan untuk memiliki kemampuan ini. Namun pada kenyataannya beberapa hasil studi menunjukkan keadaan yang kontradiktif dengan harapan.Studi yang dilaksanakan oleh
Trends in International Mathematics and Science Study (TIMSS), sebuah lembaga internasional yang mengukur kemampuan sisiwa di bidang matematika dan sains, pada tahun 2015 peringkat Indonesia di bidang matematika hanya berada di posisi 45 dari jumlah peserta seluruhnya sebanyak 50 negara. Dalam studi tersebut, siswa Indonesia hanya memperoleh skor 397 jauh di bawah rata-rata skor internasional, yaitu 500. Dari studi tersebut juga terungkap bahwa siswa Indonesia hanya menguasai soal-soalyang bersifat rutin, komputasisederhana, sertamengukur pengetahuan akan fakta yang berkonteks keseharian namun mengalami kesulitan dalam menyelesaikan soal-soal tidak rutin dan lemah dalam kemampuan mengintegrasikaninformasi, menarik simpulan, sertamenggeneralisir pengetahuan yangdimiliki ke hal-hal yang lain. Hasil studi lain yang dilakukan oleh PISA (Program for International Student Assessment), suatu studi literasi yang bertujuan untuk meneliti secara berkala tentang kemampuan siswa dalam membaca (reading literacy), matematika (mathematics literacy), dan sains (science literacy), pada tahun 2015 menunjukkan Indonesia menduduki peringkat 69 dari 76 negara dan berada di bawah rata-rata skor internasional.

Rendahnya kemampuan memecahkan masalah siswa juga dialami oleh siswa SDN Panyingkiran 1. Informasi yang penulis peroleh melalui wawancara dari salah seorang guru di sekolah tersebut mengungkapkan bahwa rata-rata kemampuan matematis siswa masih tergolong rendah. Sebagian besar siswa hanya mampu menyelesaikan soal-soal yang sama seperti yang dicontohkan guru atau mirip dengan soal-soal yang ada di buku ajar namun masih mengalami kesulitan ketika menyelesaikan soal-soal matematika yang bersifat analitis dan tidak rutin. Berdasarkan fakta-fakta di atas, dapat dikatakan bahwa kemampuan pemecahan masalah siswa pada umumnya masih rendah.

Rendahnya kemampuan pemecahan masalah siswa mengindikasikan ada sesuatu yang belum optimal dalam pembelajaran matematika di sekolah. Kemampuan pemecahan masalah dalam pembelajaran matematika dapat dikembangkan melalui berbagai aspek, salah satunya yaitu melalui pengelolan pelaksanaan pembelajaran. Dengan melakukan pengembangan perangkat 
pembelajaran melalui model pembelajaran yang relevan merupakan salah satu upaya untuk meningkatkan kemampuan pemecahan masalah siswa.

Perangkat pembelajaran (Nazarudin, 2007: 103) merupakan suatu persiapan yang disusun guru agar pelaksanaan dan evaluasi pembelajaran dapat dilakukan secara sistematis dan memperoleh hasil yang sesuai dengan harapan. Dalam Permendikbud nomor 65 tahun 2013 tentang standar proses dan Permendikbud 103 tahun 2014 tentang pembelajaran pada pendidikan dasar dan menengah mengisyaratkan bagi pendidik untuk mengembangkan perencanaan dan persiapan mengajar meliputi penyusunan silabus, rencana pelaksanaan pembelajara (RPP) dan media pembelajaran yang mengacu pada Standar Isi.

Silabus dikembangkan berdasarkan SKL dan SI untuk satuan pendidikan dasar dan menengah. Selanjutnya silabus digunakan sebagai acuan pengembangan RPP. Salah satu komponen dari RPP adalah bahan ajar. Menurut Depdiknas (2008:7) bahan ajar adalah segala bentuk bahan yang digunakan untuk membantu guru/instruktor dalam melaksanakan kegiatan belajar di kelas. Bahan ajar dapat berupa modul, buku teks, handout, CD interaktif, dan lembar kerja siswa.

Guru sebagai perancang kegiatan pembelajaran harus terampil dalam mengembangkan perangkat pembelajaran yang tepat dalam rangka membantu siswa mencapai kompetensi. Hal senada juga dijelaskan oleh Mulyasa (2009: 53) yang mengemukakan:

Tugas guru tidak hanya menyampaikan informasi kepada siswa, tetapi harus menjadi fasilitator yang memberikan kemudahan belajar kepada seluruh siswa, agar mereka dapat belajar dalam suasana yang menyenangkan, gembira, penuh semangat, tidak cemas dan berani mengemukakan pendapat secara terbuka.

Dengan perangkat pembelajaran, siswa dapat mempelajari suatu kompetensi secara runtut dan sistmatis, di mana dan kapan saja baik secara individu maupun kelompok meskipun tanpa kehadiran guru. Dengan demikian, perangkat pembelajaran memiliki peran yang sangat penting dalam pencapaian pembelajaran yang disusun guru sehingga mampu memfasilitasi siswa dalam belajar.

Mencermati penjelasan di atas akan pentingnya guru mengembangkan perangkat pembelajaran ternyata kontradiksi dengan fakta yang ada di lapangan. Berdasarkan pengamatan yang dilakukan oleh Lesley dan Labbo (Lee, 2014: 96) diperoleh data bahwa masih banyak rencana pembelajaran dan lembar kerja siswa yang belum memfasilitasi siswa untuk meningkatkan hasil belajar. Sebagian guru masih menggunakan LKS yang diproduksi secara masal. Lebih lanjut Lee (2014:97) menyatakan bahwa lembar kerja yang dibuat secara massal berdampak negatif terhadap hasil belajar siswa, sehingga mengakibatkan LKS yang dikembangkan tidak valid. Hal ini mengindikasikan masih sedikit guru yang mengembangkan LKS secara mandiri. hasil pengamatan dan telaah perangkat pembalajaran yang dilakukan oleh Suhartini dan Rusgianto (2014: 70) diperoleh data bahwa masih sedikit guru yang mengembangkan perangkat pembelajaran secara mandiri. Kebanyakan guru menggunakan perangkat pembelajaran hasil mengunduh dari internet atau menggandakan file dari rekan sesama guru. Kondisi ini mengakibatkan timbulnya kemungkinan perangkat pembelajaran yang digunakan tidak sesuai keadaan kelas, karakteristik siswa, tujuan pembelajaran atau pun pendekatan pembelajaran yang digunakan.

Perangkat pembelajaran yang digunakan harus sesuai dengan metode atau pendekatan pembelajaran diterapkan. Hal ini karena penerapan metode atau pendekatan pembelajaran yang digunakan akan berdampak pada pencapaian kompetensi siswa yang diharapkan. Sesuai pendapat Djamarah dan Aswan (2006: 3) yang mengemukakan kemampuan yang diharapkan dimiliki siswa akan ditentukan oleh kerelevansian penggunaan suatu metode yang sesuai dengan tujuan. Ini berarti tujuan pembelajaran akan dapat dicapai dengan penggunaan metode atau pendekatan yang tepat. proses pembelajaran yang dilakukan tidak serta merta hanya memindahkan ilmu pengetahuan yang dimiliki oleh guru kepada siswa secara langsung melalui ceramah, melainkan guru harus membimbing siswa untuk secara aktif mencari, mengolah, dan mengkonstruksi pengetahuan. Salah satu pendekatan pembelajaran yang dapat 
memfasilitasi hal tersebut adalah pembelajaran dengan pendekatan saintifik (scientific approcah) yang terdiri dari lima langkah diantaranya adalah mengamati, menanya, mencoba, menalar, dan mengkomunikasikan.

Pembelajaran dengan pendekatan saintifik (Barringer, 2010) adalah pembelajaran yang menuntut siswa berpikir secara sistematis dan kritis dalam upaya pemecahan masalah yang penyelesaian masalahnya tidak mudah dilihat. Pembelajaran ini akan melibatkan siswa dalam kegiatan memecahkan masalah yang kompleks melalui kegiatan curah gagasan, berpikir kreatif, melakukan aktivitas penelitian.

\section{Metode Penelitian}

Penelitian ini termasuk penelitian pengembangan yang menghasilkan produk. Produk dalam penelitian ini berupa berupa perangkat pembelajaran matematika berbasis pendekatan saintifik dengan berorientasi pada kemampuan pemecahan masalah matematika. Perangkat pembelajaran yang dikembangkan meliputi Rencana Pelaksanaan Pembelajaran (RPP) dan Lembar Kegiatan Siswa (LKS) dengan pendekatan saintifik yang berorientasi pada kemampuan pemecahan masalah. Langkah-langkah pengembangan yang digunakan dalam penelitian ini mengadaptasi dari model ADDIE yang dikembangkan oleh Dick and Carry (Muruganatham, 2016: 52). Model pengembangan ADDIE terdiri dari lima tahap, yaitu : Analysis, Design, Development, Implementation, dan Evaluation.

Subjek uji coba lapangan dalam penelitian ini adalah siswa kelas VA SDN Panyingkiran I yang berjumlah 26 orang. SDN Panyingkiran berlokasi di jalan Siliwangi Kecamatan Panyingkiran Kabupaten Majalengka.

Dalam penelitian ini, instrumen penelitian yang digunakan yaitu lembar penilaian kevalidan perangkat pembelajaran digunakan untuk mengukur kevalidan perangkat pembelajaran yang dihasilkan berupa lembar validasi RPP dan lembar validasi LKS dan instrumen tes kemampuan pemecahan masalah, lembar penilaian kepraktisan perangkat pembelajaran berupa lembar observasi dan angket respon guru dan siswa terhadap perangkat pembelajaran yang dikembangkan serta soal berupa tes kemampuan pemecahan masalah matematika siswa yang digunakan untuk mengetahui keefektifan perangkat pembelajaran matematika yang dikembangkan

\section{Hasil Penelitian}

1. Kevalidan Perangkat Pembelajaran

Penilaian perangkat pembelajaran yang di kembangkan dilakukan oleh beberapa validator yang terdiri dari ahli kurikulum, ahli materi, ahli media, dan guru. Secara rinci, hasil penilaian RPP dari masing-masing validator dapat dilihat pada tabel di bawah ini

Tabel 1

Hasil Penilaian RPP

\begin{tabular}{clcc}
\hline \multirow{2}{*}{ No } & \multirow{2}{*}{ Validator } & \multicolumn{2}{c}{ RPP } \\
\cline { 3 - 4 } & & Skor & Kategori \\
\hline 1 & Pertama & 4,65 & Sangat Baik \\
\hline 2 & Kedua & 4,85 & Sangat Baik \\
\hline & Rata-rata & 4,75 & Sangat Baik \\
\hline
\end{tabular}

Adapun hasil penilaian LKS dari masing-masing validator dapat dilihat pada tabel di bawah ini

Tabel 2

Hasil Penilaian LKS

\begin{tabular}{cccc}
\hline \multirow{2}{*}{ No } & \multirow{2}{*}{ Validator } & \multicolumn{2}{c}{ RPP } \\
\cline { 3 - 4 } & & Skor & Kategori \\
\hline 1 & Pertama & 4,41 & Sangat Baik \\
\hline 2 & Kedua & 4,57 & Sangat Baik \\
\hline & Rata-rata & 4,49 & Sangat Baik \\
\hline
\end{tabular}

Berdasarkan hasil penilaian perangkat pembelajaran di atas terlihat bahwa baik RPP maupun LKS yang dikembangkan ada kategori sangat baik. Hal ini menunjukkan bahwa pengembangan perangkat pembelajaran berbasis pendekatan saintifik yang dihasilkan valid sehingga layak diujicobakan di lapangan.

Kevalidan perangkat pembelajaran juga terlihat pada setiap aspeknya. Kevalidan RPP untuk setiap aspeknya dapat lihat pada tabel yang disajikan di bawah ini.

Tabel 3

Hasil Analisis Kevalidan RPP Tiap Aspek

\begin{tabular}{clcc}
\hline No & \multicolumn{1}{c}{ Aspek } & Skor & Kategori \\
\hline 1 & Identitas Mata Pelajaran & 4,89 & $\begin{array}{c}\text { Sangat } \\
\text { Baik }\end{array}$ \\
\hline 2 & $\begin{array}{l}\text { Rumusan } \\
\text { Indikator/Tujuan } \\
\text { Pembelajaran }\end{array}$ & 4,50 & $\begin{array}{c}\text { Sangat } \\
\text { Baik }\end{array}$ \\
\hline 3 & Pemilihan Materi & 4,50 & $\begin{array}{c}\text { Sangat } \\
\text { Baik }\end{array}$ \\
\hline 4 & Pemilihan Metode & 4,38 & Sangat \\
\hline
\end{tabular}




\begin{tabular}{clcc}
\hline & Pembelajaran & & Baik \\
\hline 5 & $\begin{array}{l}\text { Kegiatan Pembelajaran } \\
\text { dengan Pendekatan } \\
\text { Saintifik }\end{array}$ & 4,87 & $\begin{array}{c}\text { Sangat } \\
\text { Baik }\end{array}$ \\
\hline 6 & $\begin{array}{l}\text { Pemilihan Sumber } \\
\text { Belajar }\end{array}$ & 5,00 & $\begin{array}{c}\text { Sangat } \\
\text { Baik }\end{array}$ \\
\hline 7 & Penilaian & 4,63 & $\begin{array}{c}\text { Sangat } \\
\text { Baik }\end{array}$ \\
\hline
\end{tabular}

Adapun kevalidan LKS untuk setiap aspeknya dapat lihat pada tabel yang disajikan di bawah ini.

Tabel 4

Hasil Analisis Kevalidan RPP Tiap Aspek

\begin{tabular}{clcc}
\hline No & \multicolumn{1}{c}{ Aspek } & Skor & Kategori \\
\hline 1 & Kualitas Materi LKS & 4,39 & $\begin{array}{c}\text { Sangat } \\
\text { Baik }\end{array}$ \\
\hline 2 & $\begin{array}{l}\text { Kesesuaian LKS } \\
\text { dengan Pendekatan } \\
\text { Saintifik }\end{array}$ & 4,50 & $\begin{array}{c}\text { Sangat } \\
\text { Baik }\end{array}$ \\
\hline 3 & $\begin{array}{l}\text { Kesesuaian LKS } \\
\text { dengan Syarat } \\
\text { Didaktik }\end{array}$ & 4,25 & $\begin{array}{c}\text { Sangat } \\
\text { Baik }\end{array}$ \\
\hline 4 & $\begin{array}{l}\text { Kesesuaian LKS } \\
\text { dengan Syarat } \\
\text { Konstruksi }\end{array}$ & 4,44 & $\begin{array}{c}\text { Sangat } \\
\text { Baik }\end{array}$ \\
\hline
\end{tabular}

2. Kepraktisan Perangkat Pembelajaran

Kepraktisan perangkat pembelajaran diperoleh dari data hasil observasi keterlaksanaan pembelajaran, penilaian siswa dan penilaian guru.

Data hasil observasi keterlaksanaan pembelajaran digunakan untuk mengetahui keterlaksanaan langkah-langkah pembelajaran matematika pada materi pecahan dengan menggunakan pendekatan saintifik. Lembar observasi keterlaksanaan pembelajaran disusun berdasarkan RPP yang telah di kembangkan. Pengambilan data hasil observasi dilakukan sebanyak lima kali pertemuan. Data hasil observasi dapat dilihat pada tabel berikut ini.

Tabel 5

Hasil Observasi Keterlaksanaan Pembelajaran

\begin{tabular}{cc}
\hline Pertemuan ke & $\begin{array}{c}\text { Persentase } \\
\text { Keterlaksanaan }\end{array}$ \\
\hline 1 & $68,42 \%$ \\
\hline 2 & $78,94 \%$ \\
\hline 3 & $84,21 \%$ \\
\hline 4 & $89,47 \%$ \\
\hline 5 & $94,73 \%$ \\
\hline
\end{tabular}

Dari tabel di atas dapat dilihat observasi pembelajaran dengan pendekatan saintifik mengalami peningkatan persentase keterlaksanaan pembelajaran. Pada pertemuan kelima, persentase keterlaksanaan pembelajaran mencapai persentase sebesar $94,73 \%$ atau lebih dari $85 \%$. Dengan demikian berdasarkan hasil analisis tersebut, perangkat pembelajaran telah memenuhi aspek praktis dilihat berdasarkan hasil observasi proses pembelajaran.

Penilaian guru terhadap Perangkat yang dikembangkan (RPP dan LKS) dilakukan setelah pelaksanaan tahapan Implementasi, yaitu penerapan perangkat pembelajaran. Berikut dipaparkan rekapitulasi hasil penilaian guru pada tabel di bawah ini

Tabel 6

Hasil analisis Kepraktisan Perangkat Pembelajaran Berdasarkan Penilaian Guru

\begin{tabular}{clcl}
\hline No & Perangkat & Skor & Kategori \\
\hline 1. & RPP & 4.45 & $\begin{array}{l}\text { Sangat } \\
\text { Baik }\end{array}$ \\
\hline 2. & LKS & 4,38 & $\begin{array}{l}\text { Sangat } \\
\text { Baik }\end{array}$ \\
\hline
\end{tabular}

Berdasarkan hasil yang disajikan tabel di atas diketahui bahwa Skor penilaian guru terhadap RPP sebesar 4,45 dengan kategori sangat baik, sedangkan LKS sebesar 4,38 juga dengan kategori sangat baik. Dengan demikian perangkat pembelajaran yang dikembangkan masuk dalam kategori sangat baik sehingga memenuhi aspek praktis berdasarkan hasil penilaian guru.

Adapun penilaian siswa terhadap perangkat pembelajaran yang diembangkan yaitu berkaitan dengan kemudahan, kebermanfaatan, dan kesenangan dalam menggunakan LKS pada pembelajaran materi pecahan. Hasil penilaian siswa terhadap perangkat pembelajaran yang dikembangkan diperoleh hasil rata-rata sebesar 3,99 dengan kategori baik. Adapun hasil penilaian siswa terhadap perangkat pembelajaran secara lebih rinci dapat dilihat pada tabek berikut ini.

Tabel 7

Rekapitulasi hasil penialaian siswa terhadap LKS

\begin{tabular}{clcc}
\hline No. & \multicolumn{1}{c}{ Aspek } & Skor & Kategori \\
\hline 1 & Isi & 3,92 & Baik \\
\hline 2 & Bahasa & 4,10 & Baik \\
\hline 3 & Penyajian & 4,21 & $\begin{array}{c}\text { Sangat } \\
\text { Baik }\end{array}$ \\
\hline 4 & Kegrafikan & 3,86 & Baik \\
\hline & Rata-rata & 3,99 & Baik \\
\hline
\end{tabular}




\section{Total}

Berdasarkan hasil analisis data observasi keterlaksanaan pembelajaran, penilaian guru, dan penilaian siswa dapat disimpulkan bahwa perangkat pembelajaran berbasis pendekatan saintifik yang dikembangkan memnuhi kriteria praktis untuk digunakan.

\section{Keefektifan Perangkat Pembelajaran}

Keefektifan perangkat pembelajaran dalam penelitian ini ditinjau dari hasil tes kemampuan pemecahan masalah matematika siswa. Tes ini diberikan setelah penerapan perangkat pembelajaran selesai dilaksanakan. Rekapitulasi hasil tes kemampuan pemecahan masalah siswa dipaparkan dalam tabel berikt ini.

Tabel 8

Rekapitulasi hasil tes kemampuan pemecahan masalah siswa

\begin{tabular}{lll}
\hline No & \multicolumn{1}{c}{ Uraian } & \multicolumn{1}{c}{ Skor } \\
\hline 1 & Rata-rata & 79,04 \\
\hline 2 & Nilai tertinggi & 95,00 \\
\hline 3 & Nilai Terrendah & 55,00 \\
\hline 4 & Siswa yang tuntas & 23 \\
\hline 5 & Siswa yang tidak tuntas & 3 \\
\hline 6 & Persentase Ketuntasan & $88,46 \%$ \\
\hline
\end{tabular}

Berdasarkan data yang disajikan tabel di atas, rata-rata hasil tes kemampuan pemecahan masalah siswa sebesar 79,04 dengan banyak siswa yang tuntas adalah 23 orang sehingga persentase ketuntasannya sebesar 88,46\%. Dengan demikian persentase ketuntasan yang dicapai telah melebihi $80 \%$ sehingga dapat disimpulkan perangkat pembelajaran berbasis pendekatan saintifik yang dikembangkan telah memenuhi kriteria efektif.

\section{Kesimpulan}

Berdasarkan hasil pengembangan dan penelitian diperoleh pengembangan perangkat pembelajaran matematika berbasis pendekatan saintifik berorientasi pada kemampuan pemecahan masalah matematika diperoleh hasil sebagai berikut:.

1. Kualitas perangkat pembelajaran matematika berbasis pendekatan saintifik berorientasi pada kemampuan pemecahan masalah matematika ditentukan berdasarkan tiga kriteria, yaitu valid, praktis dan efektif.

2. Berdasarkan penilaian dari validator, produk yang dikembangkan berupa RPP dan LKS telah memenuhi kriteria valid dengan kualitas kevalidan sangat baik.

3. Berdasarkan penilaian guru, perangkat pembelajaran yang dikembangkan telah memenuhi kriteria praktis dengan kualitas sangat baik. Adapun siswa menilai perangkat yang dikembangkan telah memenuhi kriteria praktis dengan kualitas baik.

4. Berdasarkan hasil tes kemampuan pemecahan masalah matematika, perangkat pembelajaran yang dikembangkan telah memenuhi kriteria efektif.

\section{Daftar Pustaka}

Abidin, H. (2014). Desain Sistem Pembelajaran dalam Konteks Kurkulum 2013. Refika Aditama: Bandung.

Baringer, M.D., et al. (2010) Schools for All Kinds of Minds: Boosting Student Succes by embaracing Learning Variaton. Alexandria:ASCD.

Chambers, P. (2008). Teaching mathematics: Developing as a reflective secondary teacher. Sage Publication Inc: London.

Cho. et al. (2015). Authentic Problem Solving and learning in the 21st Century. Springer Science: Singapore.

Daryanto. (2014). Pendekatan Pembelajaran Saintifik Kurikulum 2013. Gava Media: Yogyakarta.

Djamarah, S. B. \& Zain, A. (2006). Strategi Belajar Mengajar. Rieneka Cipta: Jakarta.

Gregson, K. (2007). Understanding Mathematics. UK: Nottingham University Press.

Haylock, D. \& Thangata, F. (2007). Key Concept In Teaching Primary Mathematics. Sage: London, UK. 
Darmodjo, H. dan Kaligis, J.R.E..(1992). Pendidikan IPA II. Jakarta: Depdikbud

Hosnan, M. (2014). Pendekatan Saintifik dan Kontekstual Dalam Pembelajaran Abad 21. Bogor: Ghalia Indonesia.

Kusnandar. (2007). Guru Profesional Implementasi Kurikulum Tingkat Satuan Pendidikan (KTSP) dan Sukses dalam Sertifikasi Guru. Jakarta: Rajawali Pers.

Lee, C. D. (2014). Worksheet Usage, Reading Achievement, Classes' Lack Of Readiness, and Scence Achievement: A Cross Country Comparison. International Journal Of Education In Mathematics, Science And Technology. Vol. 2 No. 2. Hal 96-106.

Majid, A. (2006). Perencanaan pembelajaran mengembangkan standar kompetensi guru. Remaja Rosdakarya: Bandung.

Muijis, D. \& Reynolds. (2005). Effective teaching evidence and practice (2end edition). Sage Publication. London, UK.

Mulyasa. (2009). Manajemen Berbasis Sekolah. Bandung: PT. Rosdakarya.

Muruganatham, G. (2016). Developing of Econtent package by using ADDIE model. International Journal of Applied Research. Vol 1. No 3. Hal 5254.

Nazarudin. (2007). Manajemen Pembelajaran: Implementasi Konsep, Karakteristik, dan Metodologi Pendidikan Agama Islam. Yogyakarta: Teras.

Nitko, A. J. \& Brookhart, S. M. (2011). Educational Assesment of Student. Pearson Education, Inc: Boston, MA.

Polya, G. (2004). How To Solve It: A New Aspect Of Mathematical Methode. Princeton University press.
Simanungkalit, R. H. (2016). Pengembangan perangkat pembelajaran untuk meningkatkan kemampuan pemecahan masalah matematis siswa SMP Negeri 12 Pematangsiantar. Journal of Mathematics Education, Science and Technology. Vol. 1 No. 1, Juli 2016. Hal 39-56.

Sriraman, B., \& English, L. (2010). Theories of Mathematics Education. Spinger: Verlag Berlin Heidelberg.

Suprihatiningrum, Jamil. (2013). Strategi Pembelajaran Teori dan Aplikasi. ArRuzz Media: Yogyakarta.

Suhadi. (2007). Petunjuk Perangkat Pembelajaran. Surakarta: Universitas Muhammadiyah.

Suhartini \& Rusgianto, H. S. (2014). Pengembangan perangkat pembelajaran matematika siswa SMK jurusan Akuntansi di Sleman dengan pendekatan kontekstual. Jurnal Riset Pendidikan Matematika. Vol 1 No 1. Hal 69-76.

Suherman, E., dkk. (2003). Strategi Pembelajaran Matematika Kontemporer. JICA UPI: Bandung.

Trianto. (2009). Medesain Model Pembelajaran Inovatif-Progresif: Konsep Landasan, dan Implementasinya Pada Kurikulum Tingkat Satuan Pendidikan (KTSP). Jakarta : Kencana.

Wilis, J. (2010). Learning to love math: teaching strategies that change student attitudes and get results. ASCD: Alexandria Virginia. 